\title{
History of Milk Banking: From Origin to Present Time
}

\author{
Guido E. Moro
}

$\mathbf{T}$ HE ORIGINS OF DONOR human milk banking can be traced to the early practice of wet nursing, in which children were breastfed by friends, relatives, or strangers. Rules governing wet nursing are described in the Babylonian Code of Hammurabi (roughly 1800 BC), and detailed selection criteria for wet nurses have been found in centuries-old Greco-Roman texts. In these ancient times, children were thought to inherit the physical, mental, and emotional traits of their wet nurse through breast milk, so selection of the nurse was considered very important. By the 11th century, the aristocracy and royalty of Europe almost exclusively used wet nurses. Breastfeeding was considered to be indecent and ridiculous; this ideology persisted through the 1800s. In 1740, the infant mortality rate in Paris was $38 \%$, with the majority (>95\%) of infants breastfed by wet nurses. During this time, European women were making more money as wet nurses than any other occupation open to women.

The popularity of feeding by wet nurses began to decline in the 19 th century as shock and concern about depravity among wet nurses reached an all-time high and alternative milk sources (e.g., animals) were used. Studies conducted by Theodor Escherich, Chair of Pediatrics at the University of Vienna from 1902 to 1911 , demonstrated that the intestinal bacteria of breastfed neonates were significantly different than that of infants fed by other means. His efforts resulted in eventual construction of the Imperial Institute for Maternal and Infant Care and in the opening of the first human milk bank in Vienna in 1909 (Table 1). The second human milk bank opened in Boston in the following year, and more continued to open throughout the United States and Europe during the 20th century.

In 1980, the World Health Organization (WHO) and the United Nations Children's Fund (UNICEF) released a joint statement supporting the use of human donor milk as the first alternative if the biological mother was unable to breastfeed. Other organizations released similar recommendations for the use of human donor milk and established regulations for human milk banks. Human milk banks provide the service of selecting, collecting, screening, storing, and distributing donated human milk to meet the specific needs of individuals for whom human milk is prescribed by healthcare providers. In 2010, the European Milk Bank Association (EMBA) was established to promote breastfeeding and milk banking and to encourage international cooperation between human milk banks throughout Europe. The EMBA has working groups to develop European guidelines for donor milk banks, as well as to assess best practices for the processing and fortification of human milk. Currently, Holder pasteurization and standard fortification (i.e., addition of a fixed, recommended amount of multicomponent human milk fortifier to a certain volume of human milk) are the most widely used methods; however, these methods may not provide optimal nutrition, particularly in preterm infants. ${ }^{1,2}$

Today, there are $\sim 500$ human milk banks operating in more than 37 countries worldwide. In Europe, there are 210 active human milk banks, with France, Italy, and Sweden having the largest number of banks (Fig. 1); the number of human milk banks is continuously increasing. At the end of 2017, 36 human milk banks were operating in Italy, and their activity is coordinated by the Italian Association of Human Milk Banks (AIBLUD). In 2010, AIBLUD published guidelines on the establishment and operation of human milk

Table 1. History of Human Milk Banking

\begin{tabular}{|c|c|c|}
\hline 1909 & Vienna & First human milk bank in Europe \\
\hline 1910 & Boston & $\begin{array}{l}\text { First human milk bank } \\
\text { in the United States }\end{array}$ \\
\hline 1919 & Erfurt & $\begin{array}{l}\text { A model for Europe, } \\
\text { the United States }\end{array}$ \\
\hline 1943 & United States & AAP recommendations \\
\hline 1947 & Paris & $\begin{array}{l}\text { LeLong introduces human milk } \\
\text { for preterm infants }\end{array}$ \\
\hline 1975 & England & Five large banks established \\
\hline 1980 & WHO/UNICEF & Joint statement \\
\hline 1980 & United States & AAP recommendations \\
\hline 1985 & United States & HMBANA foundation \\
\hline 1993 & United States & HMBANA recommendations \\
\hline 1994 & Canada & $\begin{array}{l}\text { Canadian Paediatric Society } \\
\text { recommendations }\end{array}$ \\
\hline 1995 & France & $\begin{array}{l}\text { National law for human } \\
\text { milk banks }\end{array}$ \\
\hline 2010 & Milan & EMBA foundation \\
\hline 2014 & Italy & $\begin{array}{l}\text { National law for human } \\
\text { milk banks }\end{array}$ \\
\hline
\end{tabular}

AAP, American Academy of Pediatrics; EMBA, European Milk Bank Association; HMBANA, Human Milk Banking Association of North America; WHO, World Health Organization; UNICEF, United Nations Children's Fund.

President of the Italian Association of Human Milk Banks (AIBLUD), Milan, Italy. 
FIG. 1. Human milk banks in Europe: 2017.

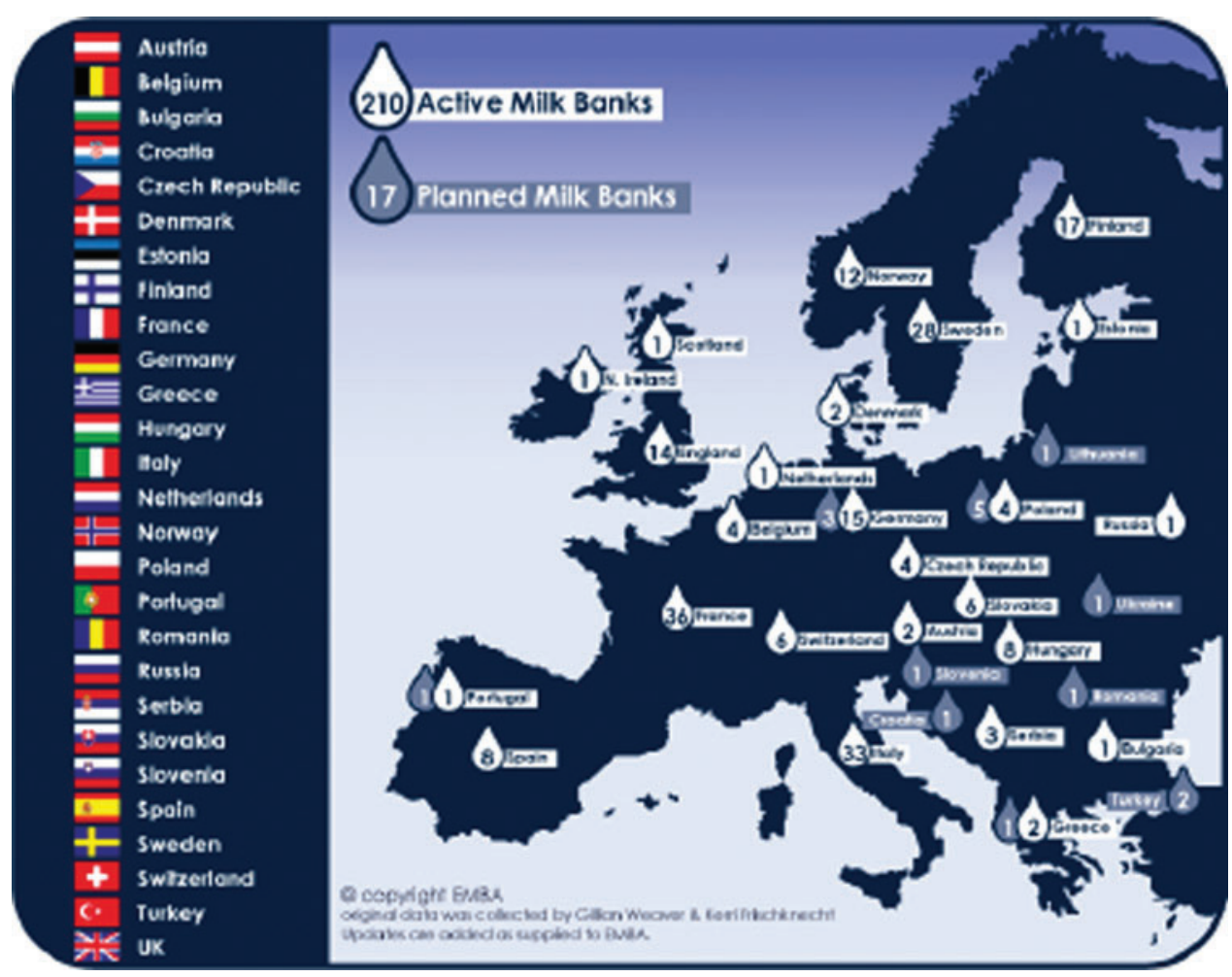

banks. $^{3}$ AIBLUD recently collaborated with the Italian Ministry of Health to develop the "Italian National Recommendations for the Organization and Management of Human Milk Banks as a Tool for the Protection, Promotion and Support of Breastfeeding." The recommendations aim to define uniform criteria for the establishment of human milk banks, define essential requirements for service and quality standards, and set control criteria for the monitoring of milk bank activities.

\section{References}

1. PATH. Strengthening Human Milk Banking: A Global Implementation Framework. Version 1.1. Seattle, Washington, USA: Bill \& Melinda Gates Foundation Grand Challenges initiative, PATH, 2013.
2. Ziegler EE. Meeting the nutritional needs of the low-birthweight infant. Ann Nutr Metab 2011;58(suppl 1):8-18.

3. Italian Association of Human Milk Banks, Associazione Italiana Banche del Latte Umano Donato (AIBLUD). Guidelines for the establishment and operation of a donor human milk bank. J Matern Fetal Neonatal Med 2010; 23(suppl 2):1-20.

Address correspondence to:

Guido E. Moro, MD

Italian Association of Human Milk Banks (AIBLUD)

Via Libero Temolo 4 Milano 20126

Italy

E-mail: guidoemoro@tiscali.it 